\title{
CYP2C9 wt Allele
}

National Cancer Institute

\section{Source}

National Cancer Institute. CYP2C9 wt Allele. NCI Thesaurus. Code C52360.

Human CYP2C9 wild-type allele is located within 10q24 and is approximately $33 \mathrm{~kb}$ in length. This allele, which encodes cytochrome P450 2C9 protein, is involved in the metabolism of drugs and xenobiotics. Certain allelic variants of the CYP2C9 gene contribute to the poor metabolizer phenotype. Conversely, one variant allele of this gene contributes to the rapid metabolizer phenotype. Functional polymorphisms in the CYP2C9 gene are associated with colorectal cancer. 